\title{
同じ流域内の 2 つのシラス台地における 地下水污染機構についての数值計算 NUMERICAL STUDY ON GROUNDWATER POLLUTION MECHANISM IN THE TWO SHIRASU PLATEAUS IN THE SAME CATCHMENT AREA
}

\author{
中川 啓 1 ・齋藤雅彦 2 ・籾井和朗 3 \\ Kei NAKAGAWA, Masahiko SAITO and Kazuro MOMII \\ 1正会員 博(工) 鹿児島大学准教授 農学部生物環境学科 (下890-0065 鹿児島市郡元1-21-24) \\ 2正会員 博(工) 神戸大学助教 自然科学系先端融合研究環 重点研究部 (广657-8501 神戸市灘区六甲台町1-1) \\ 3正会員 農博 鹿児島大学教授 農学部生物環境学科 (下890-0065 鹿児島市郡元1-21-24)
}

\begin{abstract}
Groundwater pollution by nitrate due to agricultural activities has become serious environmental issues in the two shirasu plateaus of Kasanohara and Kanoyabaru of Osumi peninsula, Kagoshima prefecture. We developed a groundwater recharge model and examined the water budget characteristics. Furthermore, two-dimensional numerical simulations were carried out to evaluate the effects of countermeasures for the contaminated source. The results of water balance analysis showed that runoff is $10-15 \%$, groundwater recharge is $65 \%$, and evapotranspiration is $20-25 \%$ of precipitation in the catchment area. The numerical results indicate that it takes 50 years for Kasanohara and 80 years for Kanoyabaru to display the effects of countermeasure of $80 \%$ reduction in concentration of the source zone. The long-term numerical simulation suggested that detailed recharge rate fluctuation rather than constant recharge rate should be applied.
\end{abstract}

Key Words : nitrate pollution, numerical simulation, shirasu plateau, groundwater recharge model

\section{1. はじめに}

鹿児島県大隈半島は，我が国有数の食糧生産基地であ るが，化学肥料や家畜粪尿が原因と考えられる硝酸性窒 素による地下水污染が問題になっている. 周辺住民は飲 料水の大部分をこの地下水に頼っているので，健康を害 する危険性が懸念されているし，このシラス台地からの 地下水や湧水は肝属川を通って志布志湾へと注いでいる ため, 河川や海域での水質悪化も眯念される.よって現 状での污染物質の動態を数值シミュレーションにより明 らかにし, 適切な対処法を確立することが求められてい る.

このように地下水污染や土䁃污染では，污染源位置や 污染拡散範囲，污染物質濃度などの情報を得ることが重 要で，その結果が対策期間やコストに影響するので，数 值計算によって限られた情報を用いて污染の実態解明や 対策効果の検討を行うことが求められる1). 例えば，有 機ヒ素化合物による地下水污染現場へ3次元数值計算を 適用し，污染メカニズムの解明を行った事例がある1), 2)
その他, 地下水污染を解析するための数值計算モデルの 開発など多数報告されている3),4).

現場を対象として解析する場合, 地表面からの涵養を どのように扱うかが結果に影響する場合がある. 解析を 簡便化するため, 平均的な降雨量や蒸発散量を与えるこ とも考えられるが，物質濃度の季節的な変動を調べる場 合や現場の水収支を正確に把握したい場合には，地下水 涵養モデルと地下水流動解析を組み合わせる方法がとら れる . 地下水涵養量の変動を考慮した污染解析の事例 は，著者の知る限りそう多くないようである．本研究で は，研究対象とした鹿児島県大隅半島のシラス台地にお いて, 地下水涵養量を評価して, それを考慮して地下水 の污染メカニズムを検討した.

研究対象とした肝属川流域では，これまでの地下水や 湧水の観測により，2つのシラス台地において硝酸性窒 素污染が明らかにされている6). 両者のシラス台地は, 地表面における窒素負荷量が異なっており, また地形地 質条件が異なっている. しかしいずれの観測地点におい ても硝酸性窒素濃度が基準值を超えている地点があるの で，それぞれの污染メカニズムを比較することは，今後， 


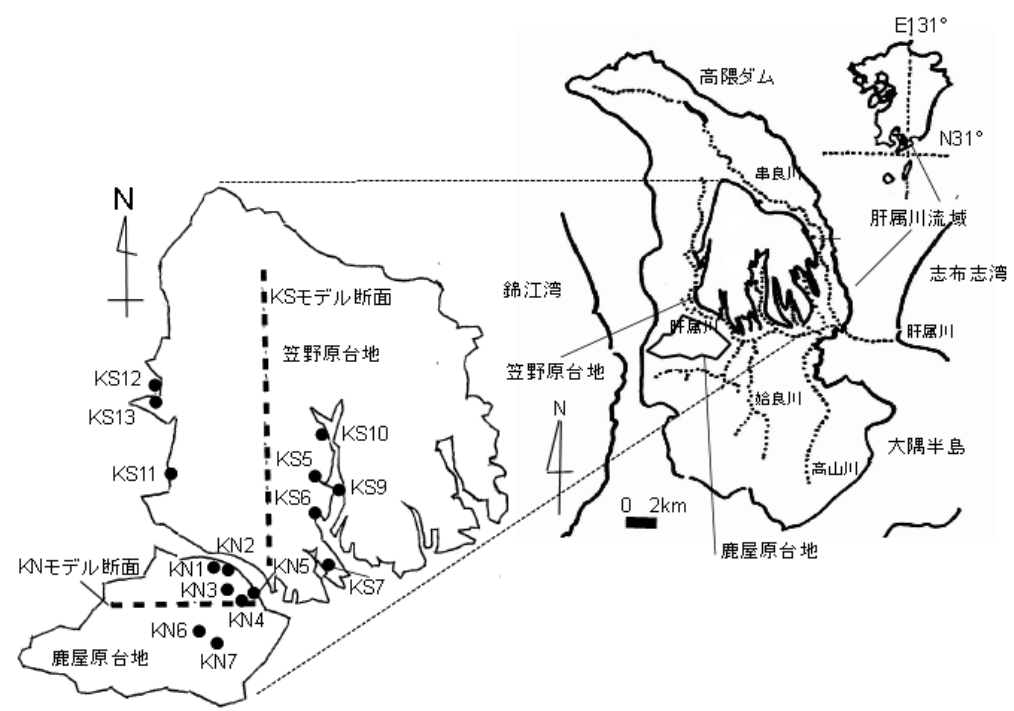

図-1 研究対象地の概要

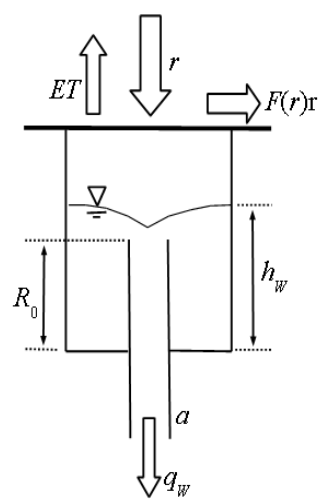

図-2 地下水涵養モデル
それぞれの台地で污染対策を講じる上で重要と考えられ る。これまでの施肥実態及び窒素収支調查により，2つ のシラス台地のうち笠野原台地の窒素負荷量は，もう一 つの鹿屋原台地に比べおよそ5倍多いことが推定されて いる.また流域内の観測地点における2004年からこれま でのモニタリング期間における期間平均硝酸性窒素濃度 の観測地点平均值は，いずれの台地においても7.5 $\mathrm{mg} \mathrm{l}^{-1}$ 程度と同程度であり, 基準值超過地点が4地点づつある ことが分かっている，なお，笠野原台地を対象とした水 文地質特性の評価》水質タンクモデルを用いた解析采が 報告されており，長期的な水質変動傾向の再現はほぼ成 功しているといえる.

本研究では, 現状再現と污染対策の効果を検討するた めの数值計算モデルの構築を試みた．まず, 地表面から の涵養量を評価するためのモデル構築を行い，研究対象 地における年間の水収支について調べた，そして2つの シラス台地における断面2次元の数值計算モデルを構築 し，地下水涵養モデルにより評価された涵養量を用いて， 污染機構および污染対策についてのシミュレーションを 実施し, 比較・検討した.

\section{2. 研究対象地の概要}

研究の対象とした肝属川流域における2つのシラス台 地（図-1）は，鹿児島県大隅半島のほぼ中央部に位置し， 笠野原台地は，肝属川と串良川に挟まれたテーブル状の 孤立した高台であり，北から南一緩やかに傾斜している

（上端部で標高約 $170 \mathrm{~m}$, 下端で20m程度）約6000ha（南 北方向 $12 \mathrm{~km}$, 東西方向 $9 \mathrm{~km}$ に拡がる面積約 $59 \mathrm{~km}^{2}$ ) のシ ラス台地である．また笠野原台地の南西部に位置寸る鹿 屋原台地は, 東西, 南北ともに $7 \sim 8 \mathrm{~km}$ 広さを持ち, 台地西部の標高60７0 mから東部の標高10 mまで西から
東に向かい緩やかに傾斜している.

これらのシラス台地は, 表層は $10 \mathrm{~m}$ 程度で, クロボク やアカホヤといった火山灰土に覆われ，その下部に15〜 $80 \mathrm{~m}$ のシラス層, その下に $7 \mathrm{~m}$ 程度の大隅降下軽石層, 垂 水砂砅層が堆積しており, これら軽石・砂砶層がシラス 台地上の主な帯水層として機能している. 後のモデル化 では, シラス層から表層まで, 軽石層, 砂礫層の3層 （鹿屋原台地は砂碩層が無い）または4層（笠野原台 地）として扱い，砂碅層下面の難透水層を不透水性境界 とした. 図中に, 笠野原台地の観測地点KS5〜 7, KS9〜 13および鹿屋原台地の観測地点KN1〜7を示す. また後 の数值計算の際のモデル断面をそれぞれの台地上に点線 で示した.

\section{3. 地下水涵養モデル}

\section{（1）モデルの概要とモデルパラメータの決定方法}

図-2に本研究で適用した地下水涵養モデルを示す5), 9). 降雨 $r$ は, 蒸発散量 $E T$ と表面流出成分 $F(r) r$ を除く, $\{1-$ $F(r)\} r-E T$ が地下浸透成分となり, タンク内一貯留される. ここで $F(r)$ は, 降雨 $r$ 直接流出率である. タンク内の水 位 $h_{w}$ が初期損失高 $R_{0}$ を超えると, 地下水への涵養が開始 される.また流出係数 $a$ を考慮した量が地下水涵養量 $q_{w}$ となる. この涵養量 $q_{w}$ は, 地下水位の上昇に寄与寸る. 以下に本モデルの基礎式を示す.なお蒸発散量の推定に は八モン式间を用いた。 まずタンク内の水位変化は次式 で与えられる：

$$
\frac{d h_{w}}{d t}=\{1-F(r)\} \cdot r-q_{w}-E T
$$

式(1)中の地下水涵養量は次式で与えられる：

$$
q_{w}=a \cdot\left(h_{w}-R_{0}\right) \times Y\left(h_{w}-R_{0}\right)
$$

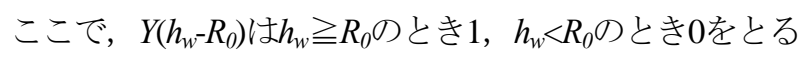




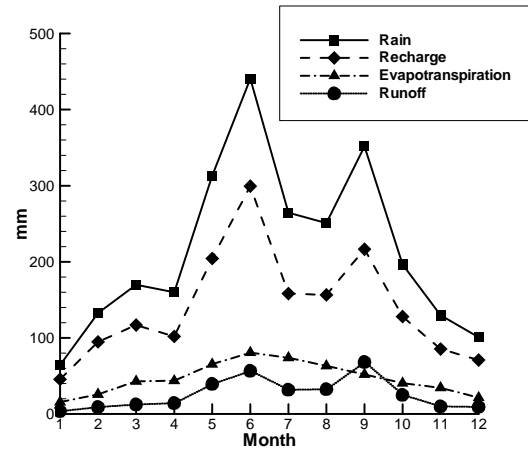

図-3 研究対象流域における年間水収支(2002 2005年の平均)

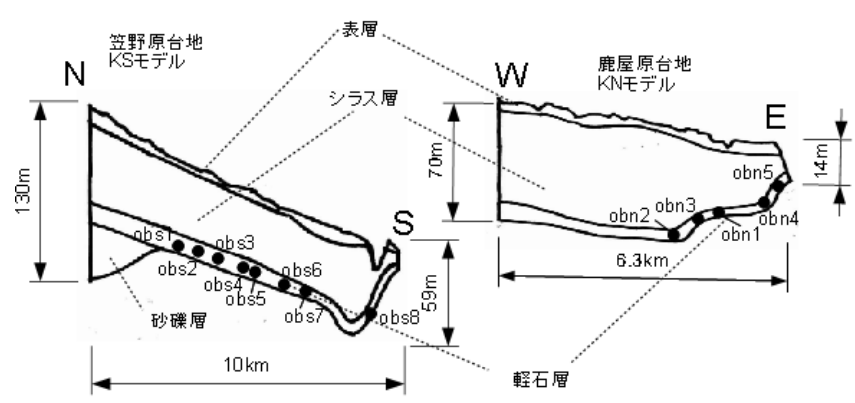

図-5 計算領域の概要 (左)笠野原台地, (右)鹿屋原台地

ステップ関数とする. また式(1)中の直接流出率は次式で 与えられる：

$$
F(r)=\frac{r}{r+r_{1 / 2}} \cdot F_{\infty}
$$

ここで, $F_{\infty}$ は $r=\infty$ に対応する $F(r)$ の極限值， $r_{12}$ は, $F(r)=F_{\infty} / 2$ に対応する $r$ の值を表すパラメータである.

未定のパラメータは初期損失高 $R_{0}$, 直接流出率に係わ る係数 $r_{12}$, 浸透係数 $a$ のつである. それぞれ， $R_{0}$ は一雨 の積算降雨量と土壌水分増加量の関係加ら土壤水分増加 に寄与しない積算降雨量として決定し， $r_{1 / 2}$ は流域末端の 河川流量の増分と流出量の合計が一致するように求め, $a$ は，笠野原台地上の圃場における年間の水収支解析 ${ }^{11}$ を参考に，涵養量が降雨量の65\%となるように決定した。 この様な評価方法であると, 水収支解析結果に大きな影 響が出ることが懸念される. しかし別に行った検討によ ると，本モデルにより評価された日流出量は，一雨毎に 評価されている流出率とも大きく相違せず，水収支の各 構成成分について，ほぼ妥当な值が導かれていることを 確認している.

\section{(2) 研究対象地における水収支の検討}

ここでは，地下水涵養モデルを用いて，流域内の水収 支について以下のように検討した．計算は日雨量などに より日毎に行った. 図-3に, 月あたりの降雨量とモデル により評価された涵養量, 流出量, 蒸発散量を, 2002 2005年の平均值で示す. 降雨量と涵養量は6月と9月に2 つのピークを持つ分布となった. 流出量もほぼそれらと
図-4 4年間(2002 2005年)の地下水涵養量

同様であったが，9月のピークの方が大きかった．蒸発 散量に関しては6月にピークを持つ分布を示した. 年あ たりで流域全体の水収支を見てみると，9月以外の月あ たりの評価と同様に，降雨量の65\%程度が地下水涵養量 であり，20２5\%が蒸発散量，10１5\%が流出量と評価 された. 鹿児島県のシラス台地の水文調査から降雨に対 する直接流出率を $10 \%$ 以下と評価した事例 ${ }^{12)}$ があること から，ほぼ妥当な評価がなされたと考えられる. 図-4に， 後の数值計算で用いる2002〜2005年の涵養モデルで評価 された地下水涵養量を示す。2002年と2003年は6月に ピークを持つ分布であったが，2004年は5，8，10月にほ ぼ同程度の最大值を持つような分布を示した．2005年は 9月に大きなピークを持つ分布となった。

\section{4. 地下水污染機構と対策効果の検討}

\section{(1) HYDRUS2D/3Dによよ数値計算の概要}

本研究では, 米国農務省塩類研究所において開発され た土中水分・溶質移動予測汎用プログラムである HYDRUS2D/3D ${ }^{13)}$ を用いて数值計算を実施した．本汎用 プログラムは, 欧米を中心に農学分野, 特に土䁃物理分 野で精力的に用いられており，様々な現象一の適用事例 も多く広く用いられている. HYDRUS2D/3Dは, 水の流 れはRichards式，溶質移動は移流分散方程式に基づき， それぞれガラーキン有限要素法によって計算される.

\section{（2）計算条件および計算に用いた諸条件}

図-1に示したそれぞれのシラス台地におけるモデル断 面における計算領域を, 図-5に示寸，笠野原台地をKS モデル，鹿屋原台地をKNモデルとする. 図-1中の観測 井戸を断面上に投影し，計算結果の観測点とし図-5に示 した. KSモデルでは，KS7をobs8，KS6をobs7，KS9を obs6, KS5をobs5, KS11をobs4, KS10をobs3, KS13をobs2, KS12をobs1とした．またKNモデルでは，KN5をobn5， KN4をobn4, KN2, 3をobn1, KN1, 7をobn3, KN6をobn2と した. KSモデルでは, 砂磎層, 軽石層, シラス層, 表 層（クロボク）の4層とし, KNモデルでは, 軽石層, シ 
表-1 数値計算に用いた諸定数

\begin{tabular}{|c|c|c|c|c|c|c|c|c|c|c|c|}
\hline \multirow{6}{*}{$\begin{array}{l} \\
\text { VGEデル } \\
\text { パラメータ }\end{array}$} & \multirow{6}{*}{$\begin{array}{c}\text { 表層 } \\
\text { シラス層 } \\
\text { 軽石層 } \\
\text { 砂礫層 } \\
\end{array}$} & \multicolumn{5}{|c|}{ KSモデル } & \multicolumn{5}{|c|}{ KNモデル } \\
\hline & & $\theta_{r}$ & $\theta_{s}$ & $\begin{array}{c}\alpha \\
(1 / \mathrm{m})\end{array}$ & $n$ & $\begin{array}{c}k_{s} \\
(\mathrm{~m} / \text { day })\end{array}$ & $\theta_{r}$ & $\theta_{s}$ & $\begin{array}{c}\alpha \\
(1 / \mathrm{m})\end{array}$ & $n$ & $\begin{array}{c}k_{s} \\
\text { (m/day) }\end{array}$ \\
\hline & & 0.33 & 0.6 & 2.41 & 1.713 & 25.92 & 0.33 & 0.6 & 3.07 & 1.871 & 8.64 \\
\hline & & 0.126 & 0.6 & 1.67 & 3.116 & 0.864 & 0.126 & 0.6 & 1.67 & 3.116 & 0.864 \\
\hline & & 0.000365 & 0.365 & 5.74 & 1.629 & 345.6 & 0.000365 & 0.365 & 5.74 & 1.629 & 345.6 \\
\hline & & 0.065 & 0.41 & 7.5 & 1.89 & 1.061 & - & - & - & - & - \\
\hline \multirow{2}{*}{\multicolumn{2}{|c|}{ 輸送パラメータ }} & \multicolumn{3}{|c|}{ 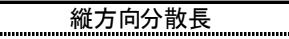 } & \multicolumn{2}{|c|}{ 横方向分散長 } & \multicolumn{3}{|c|}{ 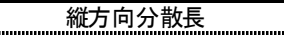 } & \multicolumn{2}{|c|}{ 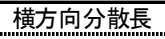 } \\
\hline & & \multicolumn{3}{|c|}{$5 \mathrm{~m}$} & \multicolumn{2}{|c|}{$0.5 \mathrm{~m}$} & \multicolumn{3}{|c|}{$5 \mathrm{~m}$} & \multicolumn{2}{|c|}{$0.5 \mathrm{~m}$} \\
\hline \multirow{2}{*}{\multicolumn{2}{|c|}{$\begin{array}{l}\text { 吸着パラメータ } \\
\text { (Freundlich型) }\end{array}$}} & \multirow{2}{*}{\multicolumn{3}{|c|}{$K_{d}$}} & \multicolumn{2}{|c|}{$\beta$} & \multicolumn{3}{|c|}{$K_{d}$} & \multicolumn{2}{|c|}{$\beta$} \\
\hline & & & & 0.845 & \multicolumn{2}{|c|}{0.68} & \multicolumn{3}{|c|}{4.79} & \multicolumn{2}{|c|}{0.55} \\
\hline
\end{tabular}

ラス層，表層（アカホヤ）の3層とした，表層の地質は， 幾つかの火山灰土が重なった多層構造であるが，笠野原 では，主なものがクロボクで，鹿屋原では，主なものが アカホヤであると仮定し，それぞれのパラメータを用い ている.

表-1に数值計算に用いたパラメータを示す. 軽石層と シラス層については共通の值を用いた。 これらの值につ いては，文献 ${ }^{14)}$ や過去の実測值”に基づいて決定した. なお，表層の火山灰土における硝酸性窒素の吸着につい ては，バッチ試験により評価された結果に基づき, Freundlich型吸着等温式のパラメータ15)を与えた。また不 飽和浸透特性の計算は, van Genuchtenモデル（VGモデ

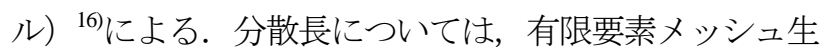
成の際のターゲットセルの大きさをKSモデルで5 m, KN モデルで7 mとしたので，ここでは両モデル全層共通で， 縦方向分散長を $5 \mathrm{~m}$ とし，横方向はその1/10とした.

境界条件は，両モデルとも両サイドを平均地下水位に 基づく静水圧分布，下部は不透水条件，上部の地表面に は，3章で評価された4年間の月ベースの地下水涵養量を 繰り返し用いた。 また比較のため, 平均涵養量を用いた 計算も実施した. 物質輸送の境界条件は, 現場で評価さ れた負荷量分布を参考にして，地表面で最も負荷強度の 高い部分にのみ, $C / C_{0}=1.0$ として与えた. 他は濃度勾配 無しとした．また，任意の圧力水頭值を領域全体に与え， 平均涵養量と両サイドの境界条件による計算を実施し, ほぼ定常状態になったものを圧力水頭の初期条件として 与えた. 濃度の初期条件は, 定常濃度分布を求める計算 においては，表層の污染源部分以外は全て $C / C_{0}=0.0$ とし た. 本研究で検討しているようなことと同様の計算を行 うために, 窒素の形態変化や土地利用サブモデルなどを 導入し，より詳細なモデル化をしている事例も報告され

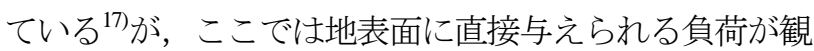
測点ではどの程度現れてくるのかといった点に着目して 検討を行っている.

\section{（3）污染機構のシミュレーション}

数值計算は，まず平均涵養量を与える場合 (KS-const およびKN-constとする）と図-4に基づく変動涵養量を与 える場合（KS-transおよびKN-trans とする）の比較を 行った. 図-6にそれぞれのモデルにおける結果を示す.
笠野原台地に関しては，涵養量変動の影響を受けやすい 観測点の細かい変動を除けば，ほぼ同様の結果が得られ た．観測点における定常濃度もほぼ同じで，obs2におけ る定常值は，污染源濃度の70\%に達した，一方，鹿屋原 台地の場合は，濃度上昇傾向や定常值に到達する時間は 同じであるが，涵養量が変動する場合は濃度が高くなっ た．この理由を調べるため，KNモデルにおいて表層の 不飽和及び吸着パラメータをKSモデルと同じクロボク とした場合もシミュレーションを行った（KNIIモデルと する）。その結果，KNIIモデルでは，濃度が定常值に到 達する時間は，KNモデルよりも短くなり，KSモデルと 同程度のおよそ50年となったが，定涵養量条件と変動涵 養量条件の結果の相違傾向は同じであった（図-6）。つ まり表層の透水性や吸着による遅延が影響しているわけ ではない，KSモデルでの結果を詳細に見てみると，変 動涵養量条件の方が，定常到達の時の濃度は高くなって おり, 平均的な強度よりも, 不連続でも大きい強度の涵 養量によって表層からの物質輸送がより促進されること が原因であると考えられる．またKNモデルは，シラス 層がKSモデルのおよそ半分と薄く, 表層から観測点ま での距離が近いため, 涵養量条件の変化の影響が出やす かったと考えられる。このように計算が長期に渡る場合, 平均化された涵養量を一定で与えると安全側に評価して しまう恐れがあるので，できるだけ現実に沿った条件で 計算が行われることが望ましいと言える. 変動涵養量の 場合のobn2における定常值は, 污染源濃度の45\%に達し た.

図一ーには，KS-trans とKN-transの定常濃度分布を示寸。 濃度急変部において若干のアンダーシュートおよびオー バーシュートが発生しているため, 比濃度に負の部分と 1.0を越えている部分が生じているが，いずれのモデル においても，主要な帯水層である軽石層まで，表層の污 染源からほぼ鉛直に移動し, 軽石層の地下水流れによっ て下流側へ運ばれる様子が示された。 この軽石層は透水 係数が大きく, 流速が大きいため, 希釈がす寸んでいる こと, 濃度の高い部分は污染源直下のシラス層中位くら いに留まっていることが分かる.

\section{（4）污染対策のシミュレーション}

続いて污染源対策の数值計算を行った. 実際の污染源 
(a)

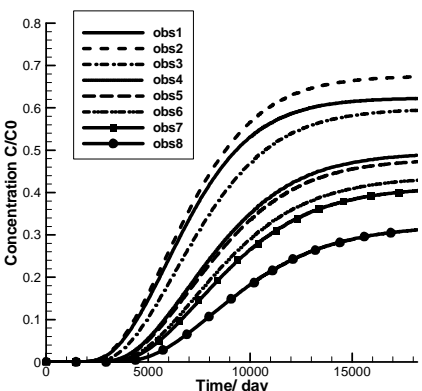

(b)

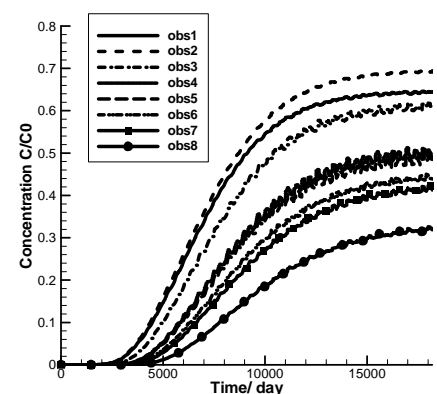

(e)

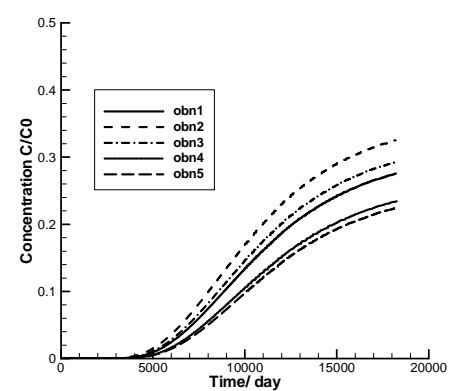

(f)

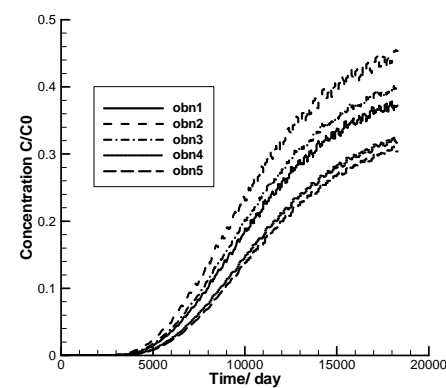

図-6 平均涵養量モデルと変動涵養量モデルの結果 (a)KS-const, (b)KS-trans, (c)KN-const, (d)KN-trans, (e)KNII-const, (f)KNII-trans

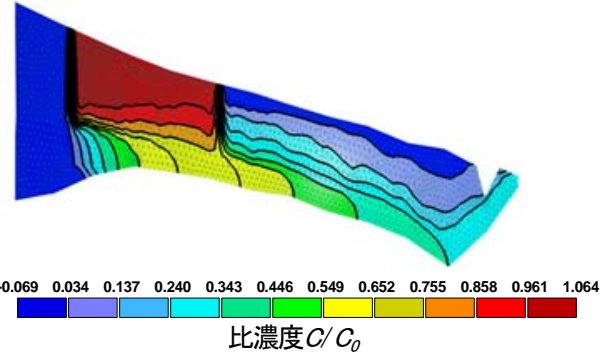

(a)
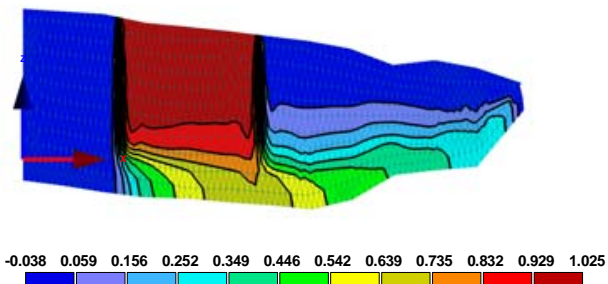

比濃度 $C / C_{0}$

(b)

図-7 定常濃度分布 (a) KS-model, (c) KN-model

対策は，家畜粪尿の処理を十分実施することや，緩効性 の化学肥料を用いることなどであるが，ここではそれら の対策によって，污染源が100\%, 80\%, 50\%削減できた場 合の効果を数值計算によって評価した．図-8にそれらの 結果を示寸，笠野原台地の場合, 100\%削減の場合は, 50 年でほぼ完全に濃度がゼロに近づく.80\%削減の場合で も30年後にはかなり低減し，地表面濃度の10\%まで低下 するが，50\%削減の場合は，obs2では36\%までにしか低 下しない. 一方, 鹿屋原台地の場合は, 80年後には, 80\%削減の対策により14\%以下には低下寸るが，50\%の 対策では26\%以下までにしか低下せず，十分とは言えな い.いずれのシラス台地においても地表面負荷量が80\% 削減に近づく程度の対策が行われれば，浄化が進むと考 えられる．また笠野原台地は50年程度で効果が出てくる が，鹿屋原台地では表層をアカホヤとした場合，効果を 見いだすのに80年程度はかかることが予想される.

\section{5. おわりに}

本研究では, 硝酸性窒素による地下水污染が問題と なっている2つのシラス台地を対象として，水収支につ いて検討を加え, さらに断面2次元の数值計算により定 常濃度分布に達寸るまでの計算と, 污染対策効果につい て検討した. その結果, 流域全体における流出量は, 降 雨量の $10 \sim 15 \%$, 地下水涵養量は65\%程度, 蒸発散量が 20〜25\%であった．また数值計算によれば，一定の涵養 量を与える場合と変動する涵養量を与える場合とでは, 結果が異なる場合があるので，できるだけ現実に即した 涵養量を与えることが望ましいと考えられる. 今回の計 算結果のみに基づくと，いずれの台地においても污染源 を現状の $80 \%$ 程度削減できるような対策がとられると浄 化が進むが，表層をクロボクとした場合の笠野原で50年 程度, 表層をアカホヤとした場合の鹿屋原で80年程度経 
(a)

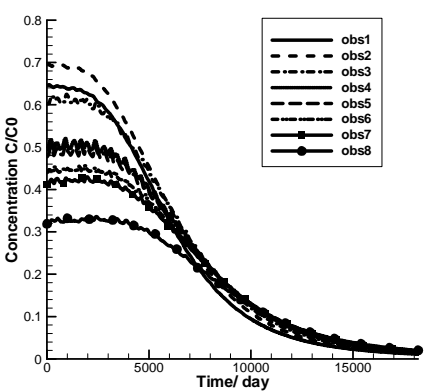

(d)

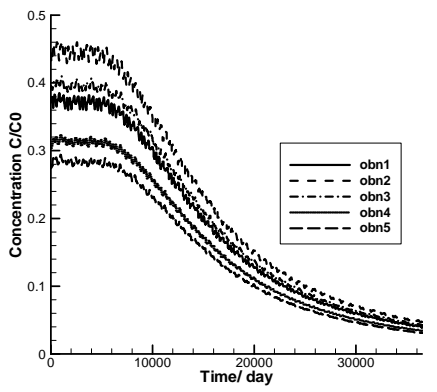

(b)

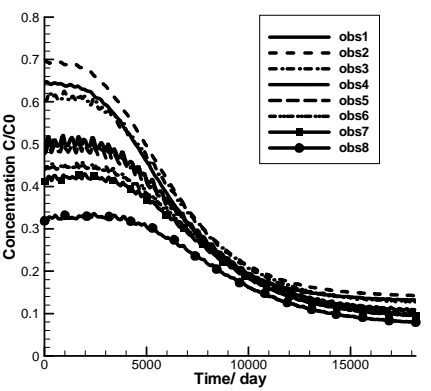

(e)

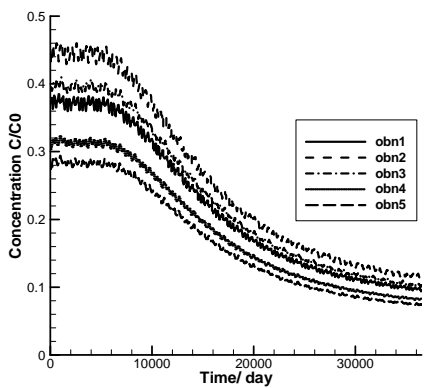

(c)

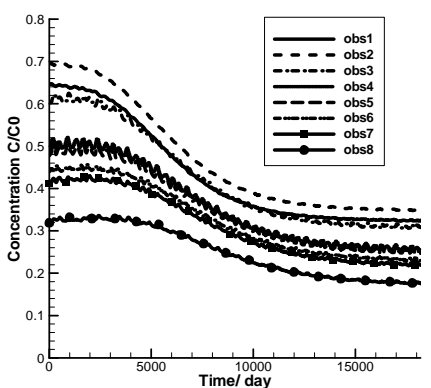

(f)

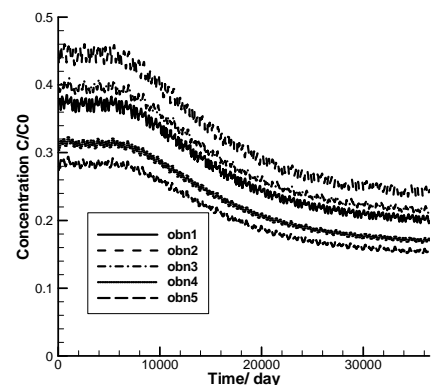

図-8 污染対策シミュレーションの結果 (a) KS-100\%, (b) KS-80\%, (c) KS-50\%, (d) KN-100\%, (e) KN-80\%, (f) KN-50\%

過しないと大きな効果は現れてこないと考えられる.

謝 辞 : 八千代エンジニヤリング(株)の高橋 努氏と金 子のぞみ氏には，データの提供及び助言をいただいた。 ここに記して謝意を表す。

\section{参考文献}

1) 江種伸之: 第6章 污染の挙動解析法, はじめて学ぶ土䁃・ 地下水污染，地盤工学会，pp.121-160, 2010.

2) Watanabe, S., Egusa, N., Jiang, X., Hirata, T., Yokoyama, N., Yamamoto, Y. and Morita, M.: Numerical Estimation on Diffusion Mechanism of Groundwater Contamination by Organic Compounds in Kamisu City, Japan., Proceedings of the 7th International Conference on Calibration and Reliability in Groundwater Modeling, ModelCARE2009, pp.413-416, 2009.

3) 黒羽陽子, 古市 徹: 微生物反応を考慮した地下水污染数值 解析-構造モデルの開発-, 日本地下水学会誌, Vol.28, No.3, pp.89-102, 1986.

4) 登坂博行, 伊藤一誠, 蛯原雅之, 稲葉 薰, 伊藤 彰, 小島 圭二: 多成分多相型移流拡散モデルによる包括的な地下水污 染解析, 日本地下水学会誌, Vol.38, No.3, pp.167-180, 1996.

5) Tsutsumi, A., Jinno, K. and Berndtsson, R.: Surface and subsurface water balance estimation by the groundwater recharge model and a 3-D two-phase flow model, Hydrological Sciences Journal, Vol.49, No.2, pp.205-226, 2004.

6) 鹿児島県農業開発総合センター大隅支場環境研究室 : 平成18 年度春夏作試験成績書 (土壤肥料), pp.1-11, 2007.

7) 久保田富次郎, 増本隆夫, 松田 周, 古江広治 : 水質環境亡 水循環からみた笠野原台地の水文地質特性, 農業工学研究所 技報, Vol.203，pp.81-100, 2005.

8) 久保田富次郎，増本隆夫，松田 周，森田重則，古江広治， 松元 順 : 笠野原大地における水文観測とモデル解析-流域
レベルの水・物質循環の解明に向けて-, 応用水文, Vol.15, pp.21-27, 2002.

9) 神野健二, 茹 瑛, 中川 啓, 細川土佐男, 田尻 要, 西山 浩司 : 塩水侵入阻止型地下ダムによる水資源開発可能量の評 価について，水工学論文集，Vol.40, pp.51-56, 1996.

10) 登坂博行 : 地圈水循環の数理-流域水環境の解析法, 東京大 学出版会, p.35, 2006.

11）田中正一, 古江広治, 脇門英美 : 南九州シラス台地上の多腐 植質厚層黒ボク土畑における年間浸透水量, 九州沖縄農業研 究成果情報, Vol.23, pp.325-326, 2008.

12) 塚田公彦：日本の水収支，市川正巳，榧根 勇編，日本の水 収支, 古今書院, pp.88-103, 1978.

13) Simunek, J., van Genuchten, Th. and Sejna, M.: The HYDRUS Software Package for Simulating the Two- and Three-Dimensional Movement of Water, Heat, and Multiple Solutes in VariablySaturated Media Technical Manual Version 1.0, 2006.

14）日本地下水学会地下水流動解析基礎理論のとりまとめに関す る研究グループ編 : 地下水シミュレーション-これだけは 知っておきたい基礎理論, 技報堂出版, pp.82-86, 2010.

15) 田中正一, 古江広治, 前田守弘 : 鹿児島県の主な畑土畩にお ける硝酸態窒素の吸着特性, 九州沖縄農業研究成果情報, Vol.23, pp.327-328, 2008.

16) van Genuchten, M.Th.: A closed-form equation for predicting the hydraulic conductivity of unsaturated soils, Soil Science Society of America Journal, Vol.44, No.5, pp.892-898, 1980.

17) 久保田富治郎, 松森堅治, 吉永育生, 加藤英孝, 板橋 直, 吉永秀一郎, 坪山良夫, 加藤正樹, 森 康二, 多田和広 : 流 域管理を目的とした農業環境対策シミュレーターの開発-三 次元水・物質モデルの恋瀬川流域への適用-, 農林水産省農 林水産技術会議事務局「自然共生」プロ研究推進事務局編,

「農」における自然との共生III, pp.23-42, 2007.

(2010. 9. 30受付) 